\title{
The impact of applying foliar fertilizers on the health condition of maize
}

\author{
Dalma Rácz - László Radócz \\ Institute of Plant Protection, Faculty Of Agricultural and Food Sciences and Environmental Management, University of Debrecen, \\ H-4032 Debrecen, Böszörményi út 138. \\ racz.dalma@agr.unideb.hu
}

\begin{abstract}
SUMMARY
The nutrient supply of plants is becoming more important in plant protection since the appropriate condition of plants can be ensured by optimal and satisfactory nutrient supply to avoid nutritional deficiency diseases. Due to the extreme weather conditions, plants are forced to face several stress factors, which leads to deterioration of the plant health. The increasing occurrence of droughts poses threat to nutrient uptake through the roots since all the nutrients can be accessible to the plants only if they are in dissolved form in the soil - which is not possible in the absence of water. Therefore, the importance of foliar fertilizer is becoming a more and more significant part of the nutrient supply, because with the help of this technology the development of any nutrient deficiency can be prevented.

In this experiment, we focused on the efficiency of two different foliar fertilizers on maize. Foliar fertilizers were applied two times, once in the stage with 8 leaves and tasseling phenophase of the maize. To verify the efficiency of the foliar fertilizers, the chlorophyll content of untreated and treated plant's leaves was measured after each application. Moreover, the length and diameter of maize cobs, thousand kernel weight, protein, oil and starch content were also measured, and the results were compared to the untreated (control) ones. According to the results, in all aspects significant differences were observed and due to the laboratory analysis of leaves, in the case of magnesium and zinc supply the foliar fertilizers were able to prevent the development of nutrient deficiency.
\end{abstract}

Keywords: plant nutrition, foliar fertilizer, maize, condition of plants, micronutrient-deficiency

\section{INTRODUCTION}

It has been known well that there is a close correlation between the plant's nutrient supply and the resistance to different diseases. In other words, in disease control, the importance of nutrient supply is becoming a more and more significant part of the sustainable plant protection. For instance, it is widely known that the defensive system of plants against pathogens with optimal $\mathrm{P}$ - and $\mathrm{K}$ nutrient supply is much stronger than plants suffering insufficient nutrient supply (Perrenoud, 1990; Jaiswal et al., 2016; Achary et al., 2017). However, it doesn't mean that pathogens attacked plants can be controlled only by appropriate nutrient supply, but a professional nutrient supply can strongly support and intensify the quality and success of protective technologies (Reuveni and Reuveni, 1998; Gupta et al., 2017; Reddy, 2017). Basically, the reason for the development of any nutrient deficiency is the lack of nutrient content in cells, thus in case of deficiency of $\mathrm{N}, \mathrm{P}, \mathrm{S}, \mathrm{Mg}, \mathrm{Ca}$ etc. which are components of essential cells. Developmental disturbances may occur that inflict inhibition in plant growth (Füleky and Sárdi, 2014).

In recent years the micronutrient supply has received increasing emphasis since these nutrients are needed only at low level in plants, still, they have several physiology effects that improve the condition of plants and contribute to higher and better quality yield (Bergmann, 1979; Kádár, 2016).

Depending on which nutrient is deficient in the plant, different types of symptoms can be observed. In case of mobile nutrients - such as $\mathrm{N}, \mathrm{P}, \mathrm{K}, \mathrm{Mg}-$ symptoms occur primarily on the older parts of the plant, since these nutrients can transport from older parts to the younger, still developing parts. On the other hand, in the case of immobile nutrients $(\mathrm{Fe}, \mathrm{S}, \mathrm{B}, \mathrm{Ca})$, symptoms occur in younger parts of the plant (Bergmann, 1979, Gupta et al., 2008; Muthomi, 2015).

In plant protection, the importance of latent or hidden nutrient deficiency is not emphasized enough, although due to the invisible nutrient deficiencies crops suffer from several health problems which means that it is much easier for pathogens and pests to attack crops. Therefore, it poses an even greater threat to the success of plant protection. Latent nutrient deficiency is often developed when the lack of an essential nutrient is minor. However, if the amount of any nutrient is minimal, the concentration of another nutrient may increase. It was confirmed by an experiment where doubled $\mathrm{Fe}$ and $\mathrm{Mn}$ concentrations in $\mathrm{Cu}$-deficient peppers were observed while in another experiment the higher concentration of $P$ level was observed in case of the lack of Zn (Bergmann, 1979).

To determine which nutrient caused deficiency is a particular challenge for every grower. Although the lack of each nutrient develops characteristic symptoms, in practice, in many cases deficiency symptoms are indicated by not only one, but more nutrients. These are called multiplex symptoms (Patócs, 1999), which can be determined only with the help of professional, laboratory analyses. This test reveals the whole nutrient supply status in plants and can predict the deficiency disease. With leaf analysis, farmers can ensure whether those plants are well supplied with nutrients (Cerling, 1971; Jezek et al., 2015).

According to several previous data, all plants are highly sensitive to the absence of any nutrient. Maize usually produces the symptoms of zinc deficiency at a very early stage, which can inflict less yield (Gupta et al, 2008; Mattiello et al., 2015) since this nutrient plays an important role in protein metabolism and in the 
production of auxin. The characteristic symptoms of zinc deficiency are that the maize develops extremely tiny leaves and general chlorosis of leaves can be also observed, however, the median and lateral veins remain green. The leaves stand upright and easily fragmented. Due to the absence of auxin short stem can develop (Nagy and Kovács, 2005; Gallavotti, 2013).

\section{MATERIALS AND METHODS}

The research aimed to examine the effects of two foliar fertilizers on maize's health and to detect the potential nutrient deficiency disease by laboratory leaf analysis. The experiment was set up at the University of Debrecen, Plant Protection Institute's demonstration garden, which was designed in small plots ( 1 parcel $=$ $15 \mathrm{~m}^{2}$ ), and each treatment were repeated 4 times, taking care not to place two parcels with the same treatment. Besides the two treatments using foliar fertilizers, control/untreated parcel was used for comparison.

The test crop was maize (Armagnac, KITE Zrt.), which was seeded on the $3^{\text {rd }}$ of May. The two foliar fertilizers were applied twice, on the $28^{\text {th }}$ of June and $11^{\text {th }}$ of July. The two foliar fertilizers have nearly similar nutrient content, basically, both of them have general composition, including microelements as well. One of them also contented alga extract (Figure 1) The doses of the two foliar fertilizers were the maximum dose recommended by the producer (foliar fertilizer 1 : $101 \mathrm{ha}^{-1}$, foliar fertilizer 2: $41 \mathrm{ha}^{-1}$ ).

Table 1

The nutrient content of the two applied foliar fertilizers

\begin{tabular}{ccc}
\hline $\begin{array}{c}\text { Nutrient } \\
\left(\mathrm{g} \mathrm{ha}^{-1}\right)\end{array}$ & $\begin{array}{c}\text { Foliar fertilizer 1 } \\
\left(101 \mathrm{ha}^{-1}\right)\end{array}$ & $\begin{array}{c}\text { Foliar fertilizer 2 } \\
\left(41 \mathrm{ha}^{-1}\right)\end{array}$ \\
\hline $\mathrm{N}$ & 800 & 240 \\
$\mathrm{P}$ & - & 52 \\
$\mathrm{~K}$ & 700 & 132 \\
$\mathrm{~S}$ & 700 & - \\
$\mathrm{B}$ & 1.27 & 10 \\
$\mathrm{Cu}$ & 1.62 & 6 \\
$\mathrm{Fe}$ & 2.84 & 12 \\
$\mathrm{Mn}$ & 2.65 & 12 \\
$\mathrm{Zn}$ & 0.38 & 16 \\
Mo & - & 2 \\
Algae extract & - & 240 \\
\hline
\end{tabular}

To verify the efficiency of foliar fertilizer chlorophyll content of leaves was measured two times. As it has been known well, there is a close correlation between the content of chlorophyll and the health condition of crops. Therefore, after the treatment with foliar fertilizers, chlorophyll content was measured twice: $3^{\text {rd }}$ and $16^{\text {th }}$ of July. For measurements, Minolta SPAD-502 equipment was used. We performed 3 measures per leaf, and data were averaged. Also, older and young leaf were measured.
To prove that using foliar fertilizers strongly improves the nutrient supply in maize, laboratory leaf analysis was conducted as well that showed the total amount of each nutrient in crops. To conduct valid leaf analysis 20-20 leaf samples were needed from each treatment. During the laboratory leaf analysis Pol-EkoAparatura SLW 240 drying equipment was used for the preparation of samples from which extraction was performed with $\mathrm{HNO}_{3}-\mathrm{H}_{2} \mathrm{O}_{2}$ blend with CEM Mars-6 microwave digester. The nitrogen content of the extracts was determined on a Velp Scientifica UDK 139 instrument and the other nutrients were determined on a Thermo Scientific iCAP 6300 Radial View ICPOES spectrometer (HL-LAB).

According to the theory, as foliar fertilizers can contribute to higher yield and improve biomass production, the length and diameter of maizecobs, and thousand kernel weight were also measured. For statistical analysis, 20-20 cobs were needed and measured. For measuring the diameter, we used digital caliper at half of the cob. Since foliar fertilizers can improve the quality of yield, protein, oil and starch content were measured by Foss Infratech 1241 Grain Analyzer.

To statistical analysis, the mean and standard deviation of 20 independent measurements were determined. Significance tests were performed with R programming language ( $\mathrm{R}$ Core Team, 2019) using Student's t-test or Mann-Whitney U test depending on the distribution of sample means. Only differences at $\mathrm{p}<0.05$ probability levels were significant.

\section{RESULTS AND DISCUSSION}

According to the results of the chlorophyll content, both times significant differences were observed (Figure 1, 2). Mainly the older leaves are more important since these leaves can indicate more intensively the status of the condition, while younger leaves show the quality of transportation of mobile nutrients. In other words, due to the two foliar fertilizers significantly higher chlorophyll content was measured compared to the untreated plants. However, it is also important to emphasize that there was no significant difference in effect between the foliar fertilizers, which means that the efficiency of the two products was nearly the same.

To underline the results of chlorophyll measurement, also laboratory leaf analysis was conducted which gives information about the nutrient content in crops, and highlights the potential nutrient deficiencies. According to the result of analysis, in case of $\mathrm{Mg}$ and $\mathrm{Zn}$ nutrients, the use of foliar fertilizers was able to prevent the nutrient deficiency disease since none of them have reached the lower critical nutrient content level (Mg: $2500 \mathrm{mg} \mathrm{kg}^{-1}$, Zn: $25 \mathrm{mg} \mathrm{kg}^{-1}$; Elek és Kádár, 1980) however, no any symptoms could be observed (Table 2). It puts the emphasis on the latent nutrient deficiency, which is just as harmful as any other disease caused by pathogens. The result of leaf analysis also confirmed the increased sensitivity of maize against zinc deficiency. 


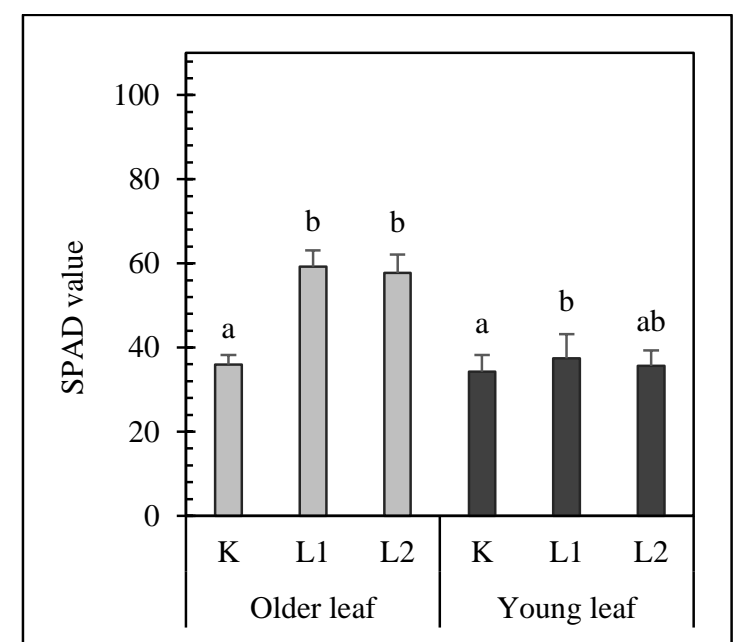

Notation: K; Controll, untreated maize; L1: Foliar fertilizer 1; L2: Foliar fertilizer 2; $<<0.05$

Figure 2: The chlorophyll content of leaves (16.07.2019)

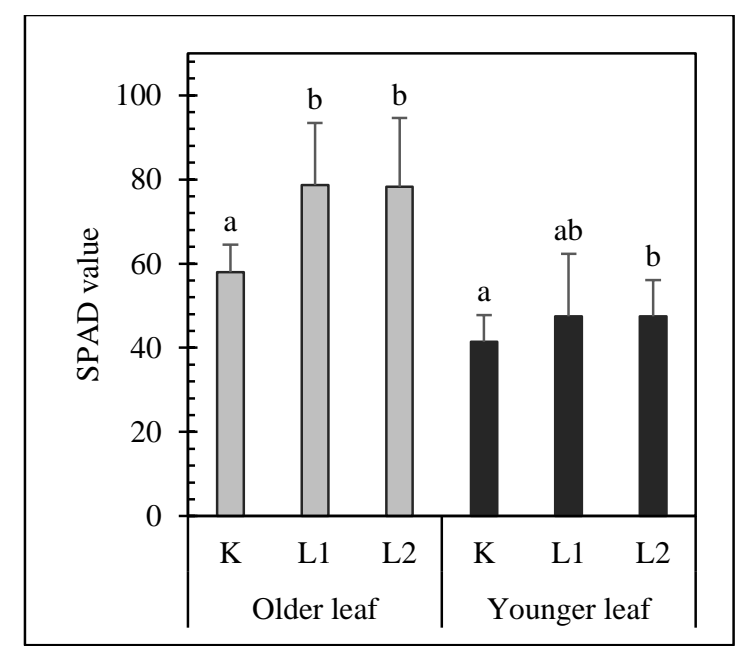

Notation: K; Controll, untreated maize; L1: Foliar fertilizer 1; L2: Foliar fertilizer 2; $<<0.05$
Nutrient content in leaves

\begin{tabular}{cccc}
\hline $\begin{array}{r}\text { Nutrient } \\
\left(\mathrm{mg} \mathrm{kg}^{-1}\right)\end{array}$ & $\mathrm{C}$ & Treatments & $\mathrm{L} 1$ \\
\hline $\mathrm{N}$ & $30200 \pm 1510$ & $31700 \pm 1585$ & $31200 \pm 1560$ \\
$\mathrm{P}$ & $2660 \pm 106$ & $2800 \pm 112$ & $2750 \pm 110$ \\
$\mathrm{~K}$ & $19960 \pm 798$ & $18050 \pm 722$ & $18940 \pm 758$ \\
$\mathrm{Ca}$ & $5520 \pm 414$ & $6040 \pm 453$ & $6100 \pm 458$ \\
$\mathrm{Mg}$ & $2400 \pm 180$ & $2960 \pm 222$ & $3070 \pm 230$ \\
$\mathrm{~S}$ & $2120 \pm 212$ & $2110 \pm 211$ & $2150 \pm 215$ \\
$\mathrm{~B}$ & $32 \pm 4$ & $44 \pm 6$ & $45 \pm 6$ \\
$\mathrm{Cu}$ & $13.8 \pm 1$ & $13.4 \pm 1$ & $12.9 \pm 1$ \\
$\mathrm{Fe}$ & $123 \pm 6$ & $101 \pm 5$ & $115 \pm 6$ \\
$\mathrm{Mn}$ & $102 \pm 5$ & $108 \pm 5$ & $112 \pm 6$ \\
$\mathrm{Zn}$ & $23.5 \pm 1$ & $34.5 \pm 2$ & $30.6 \pm 2$ \\
\hline
\end{tabular}

Notation: This table shows the results of the laboratory leaf analysiswhich determined the maize's nutrient content.

C: Controll, untreated maize; L1: Foliar fertilizer 1; L2: Foliar fertilizer

According to the results of the length and diameter of maizecobs, a significant difference was observed as well (Figure 3). As can be seen from the figures, there was no efficiency difference between the two applied foliar fertilizers, however, both of them highly surpassed the results of untreated maizes. These results underline the fact that using foliar fertilizer can contribute to even more intense biomass production.

According to several previous types of research, there is significant correlation between foliar fertilizers and the amount of yield. According to the measurements, the thousand kernel weight increased due to the two foliar fertilizers. Further, in terms of quality, the protein, oil, and starch content were measured as well. Results show that due to the foliar fertilizers, the starch content increased the most, and the protein content increased slightly, as well as the foliar fertilizers were not able to influence the oil content (Figure 4, 5, 6).

Figure 3: Measurments of the length and diameter of maizecob

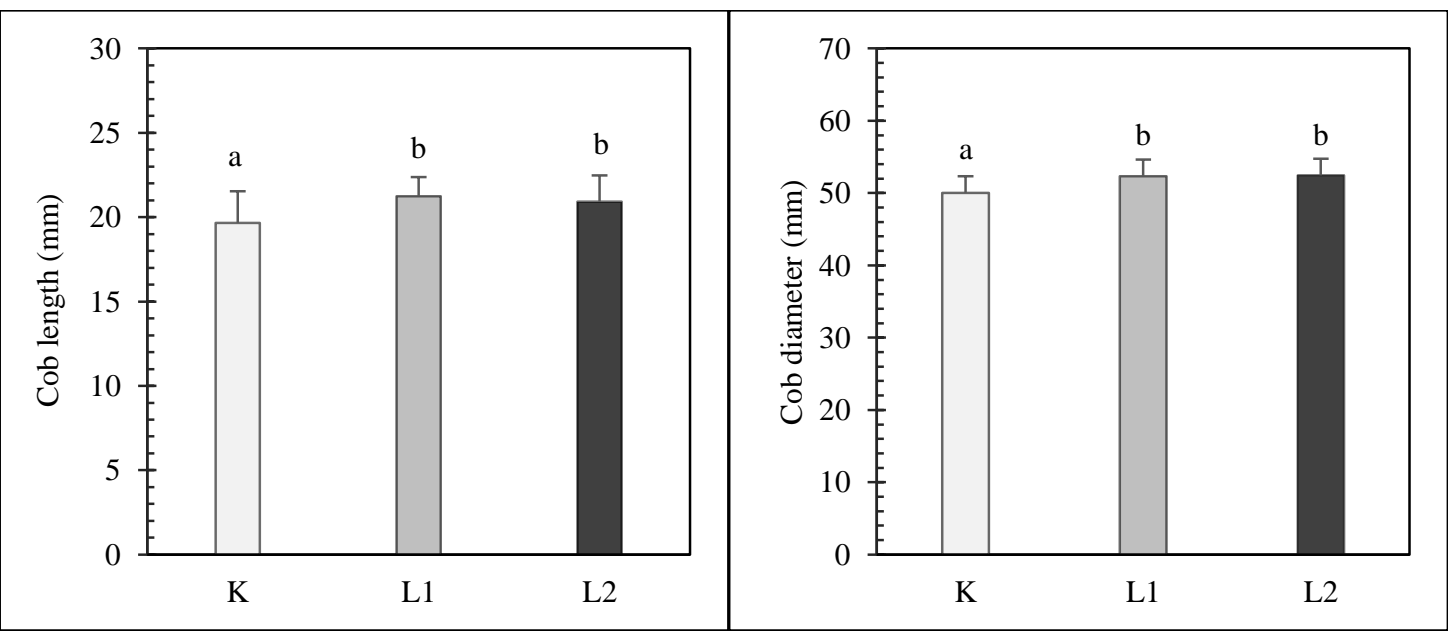

Notation: K=Controll, untreated maize; L1: Foliar fertilizer 1; L2: Foliar fertilizer 2; $<<0.05$ 
Figure 4, 5, 6: The quality parameters of maize (protein, oil and starch content) and it's relation to the thousand kernel weight

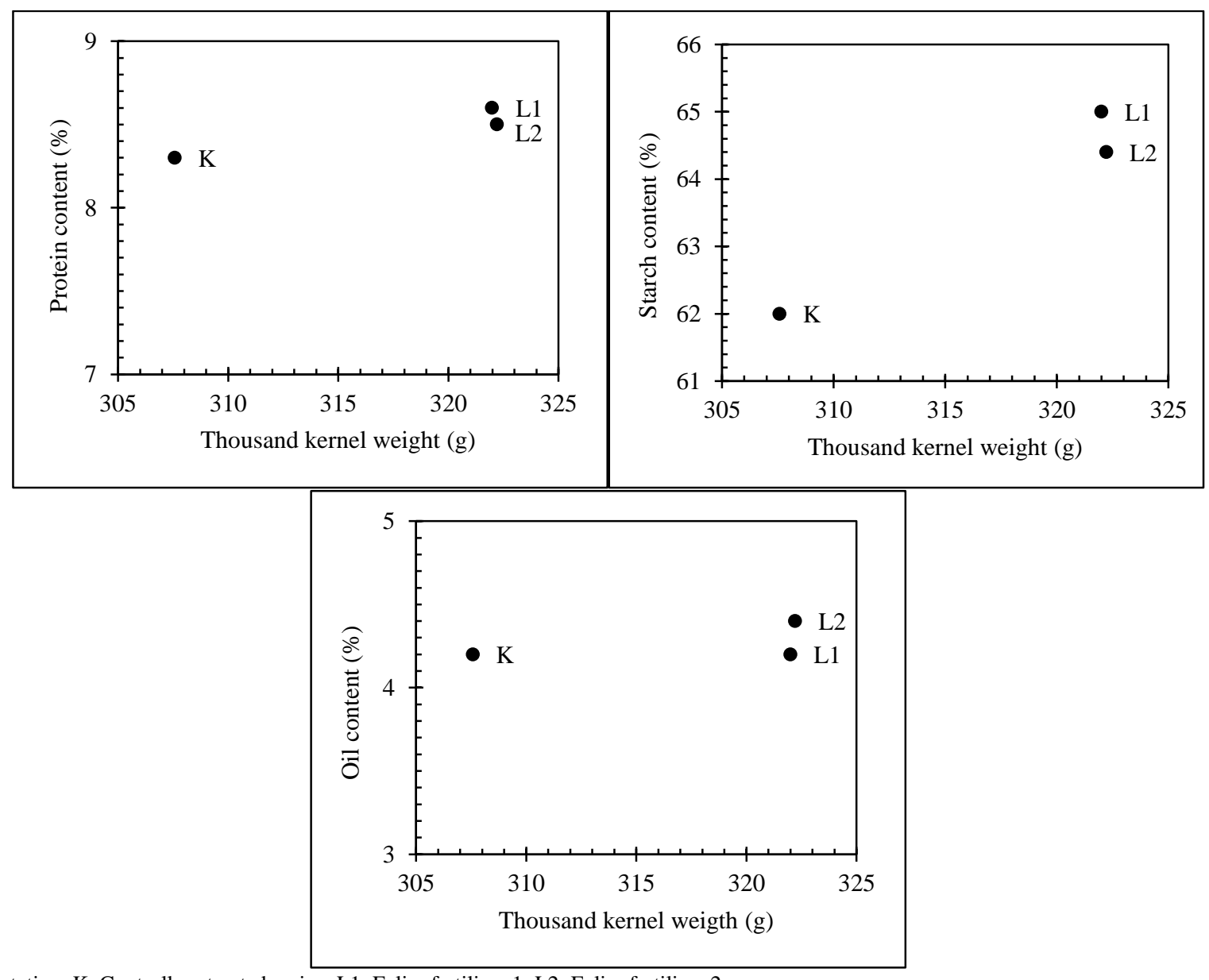

Notation: K: Controll, untreated maize; L1: Foliar fertilizer 1; L2: Foliar fertilizer 2

\section{CONCLUSION}

Due to the extreme weather conditions, there is a growing demand for technologies that strengthen the stress-tolerance of crops. With sufficient and professional nutrient supply the condition of the treated crops can improve, thus, the risk of crops being destroyed by pathogens can be reduced. It is highly important to put the emphasis on the micronutrient supply since there is still only a little awareness of the key role of each nutrient. For instance, in the case of maize, it requires an increased presence of zinc, otherwise lower and poor-quality yield should be expected. Furthermore, these micronutrients are essential in several physiological processes which can improve the condition of crops. With the aim to confirm all these facts, in this experiment two different foliar fertilizers were tested in maize for two times. After each application, older and younger leaf's chlorophyll content was also measured, since it can give a piece of good information about the condition of crops.

According to the results, the effect of two foliar fertilizers was fully manifested, because compared to the untreated maize, significantly higher chlorophyll content was measured in the treatments. However, there was no difference between the two tested foliar fertilizers in terms of efficiency. Furthermore, laboratory leaf analysis showed that due to the foliar fertilizers, in the case of $\mathrm{Mg}$ and $\mathrm{Zn}$, the nutrient deficiency disease was successfully prevented. This raises the awareness of latent nutrient deficiency because no symptoms were showed by the maize. To prove that there is a close correlation between biomass production, the amount of yield and effect of foliar fertilizer, the length and diameter of maize cobs, and thousand kernel weight were observed. There was a significant difference due to the foliar fertilizers, but again, there was no distinction between the two fertilizers in effect. To underline that even the quality parameters of the yield can be improved, the protein, oil and starch content were also measured, and results showed that only in case of protein and starch content quality improvement was observed, but not in oil content. To sum up the results, in this experiment the beneficial effects of using foliar fertilizers were successfully proved. However, due to global warming, crops are increasingly exposed to more and more stress factors, thus, technologies which help to avoid these adverse stress effects are needed more than ever. 


\section{REFERENCES}

Achary, V. M. M.-Ram, B.-Manna, M.-Datta, D.-Bhatt, A.-Reddy, M. K.-Agrawal, P. K. (2017): Phosphite: a novel P fertilizer for weed management and pathogen control. Plant Biotechnolgy Journal, 15 (12): 1493-1508. DOI: https://doi.org/10.1111/pbi.12803

Bergmann, W. (1979): Termesztett növények táplálkozási zavarainak előfordulása és felismerése. Budapest, Hungary: Mezőgazdasági Kiadó.

Cerling, V. (1971): The diagnostics of plant nutrition. New Delhi, India: Proc. Int. Symp. Of Soil Fertility Evaluation, 211-217.

Elek, É.-Kádár, I. (1980): Állókultúrák és szántóföldi növények mintavételi módszere. Budapest, Hungary: MÉM Növényvédelmi és Agrokémiai Központ.

Füleky, Gy.-Sárdi, K. (2014): Tápanyag-gazdálkodás mezőgazdasági mérnököknek. Budapest, Hungary: Mezőgazda Kiadó.

Gallavotti, A. (2013): The role of auxin in shaping shoot architecture, Journal of Experimental Botany, 64(9): 2593-2608. DOI: https://doi.org/10.1093/jxb/ert141

Gupta, U. C.-Kening, W. U.-Siyuan, L. (2008): Micronutrients in soils, crops, and livestock. Earth Science Frontiers, 15(5):110 125.

Gupta, N.-Debnath, S.-Sharma, S.-Sharma, P.-Purohit, J. (2017): Role of nutrients in controlling the plant diseases in sustainable agriculture. In: Meena, V. S.-Mishra, P. K.-Bisht, J. K.Pattanayak, A. (eds.) Agriculturally important microbes for sustainable agriculture. Singapore: Springer, 217-262. DOI: https://doi.org/10.1007/978-981-10-5343-6_8

Jaiswal, D. K.-Verma, J. P.-Prakash, S.-Meena, V. S.-Meena, R. S (2016): Potassium as an Important Plant Nutrient in Sustainable Agriculture: A State of the Art. In: Meena, V.-Maurya, B.Verma, J.-Meena, R. (eds.) Potassium Solubilizing Microorganisms for Sustainable Agriculture. New Delhi, India: Springer, 21-29. DOI: https://doi.org/10.1007/978-81-3222776-2_2
Jezek, M.-Geilfus, C. M.-Bayer, A.-Mühling, K. H. (2015): Photosynthetic capacity, nutrient status, and growth of maize (Zea mays L.) upon $\mathrm{MgSO}_{4}$ leaf-application. Frontiers in Plant Science, 5: 781 DOI: https://doi.org/10.3389/fpls.2014.00781

Kádár, I. (2016): Principles and methods in plant nutrition. Budapest, Hungary: Research Institute for Soil Science and Agricultural Chemistry, Department for Agricultural Chemistry and Plant Nutrition.

Mattiello, E. M.-Ruiz, H. A.-Neves, J. C. L.-Ventrella, M. C.Araújo, W. L. (2015): Zinc deficiency affects physiological and anatomical characteristics in maize leaves. Journal of Plant Physiology, 183: 138-143. DOI: https://doi.org/10.1016/j.jplph.2015.05.014.

Muthomi, J. (2015): Abiotic disorders in seed production. Nairobi, Kenya: Seed Enterprise Management Institute (SEMIs), University of Nairobi.

Nagy, J.-Kovács, J. (2005): A Gyümölcsfák nem fertőzö betegségei és talajmüvelésük. Debrecen, Hungary: Debreceni Egyetem AGTC.

Patócs, I. (1989): A növények táplálkozási zavarai és betegségei. Budapest, Hungary: Agroinform.

Reddy, P. P. (2017): Agro-ecological approaches to pest management for sustainable agriculture. Singapore: Springer. DOI: https://doi.org/10.1007/978-981-10-4325-3

Perrenoud, S. (1990): Potassium and Plant Health. Bern, Switzerland: International Potash Institute.

Reuveni, R.-Reuveni, M. (1998): Foliar-fertilizer therapy - a concept in integrated pest management. Crop Protection, 17(2):111-118. 
